\title{
Recovering from a punch in the mouth - the need for continuous adaptation to COVID-19
}

\section{Don Nutbeamª,bo}

a Editor-in-Chief, Public Health Research \& Practice

b School of Public Health, University of Sydney, NSW, Australia

c Corresponding author: don.nutbeam@sydney.edu.au

\section{Article history}

Publication date: September 2021

Citation: Nutbeam D. Recovering from a punch in the mouth - the need for continuous adaptation to COVID-19. Public Health Res Pract. 2021;31(3):e3132114. https://doi.org/10.17061/phrp3132114
In 1997 Mike Tyson fought Evander Holyfield for the world heavyweight boxing championship. When Tyson was asked by a reporter whether he was worried about Holyfield and his fight plan, he answered: "Everyone has a plan until they get punched in the mouth". The use of a boxing analogy and reference to Tyson in a public health journal will not be to everyone's taste, but Tyson's response to 'the man with a plan' resonates with the situation being experienced in several parts of the world that have had success in suppressing and even eliminating coronavirus disease 2019 (COVID-19) in their populations.

In this edition of the Journal, we have an excellent overview from Capon and colleagues ${ }^{1}$ of lessons learned from the assertive implementation of testing, tracing and restrictions in movement to manage three waves of the epidemic in Australia. Rather ominously, the paper contains an addendum indicating that, as the paper was being prepared for publication, a fourth wave of COVID-19 was being experienced in Sydney, driven by the Delta variant.

Bennett's perspective paper picks up from this addendum, and reflects on the current experience of the COVID-19 Delta variant. ${ }^{2}$ This paper describes how a state such as New South Wales in Australia, widely acknowledged to have managed the pandemic successfully, can be thrown completely off balance by a metaphorical punch in the mouth. The speed of transmission of the Delta variant overran the established approaches to testing, tracing, restrictions in movement, isolation and quarantine that worked previously. As Bennett observes, "The Delta variant has usurped one important decision we thought was in our control - when we would let the virus in."

Bennett provides a sophisticated and elegant analysis of the consequences of this loss of control, and the challenges to those deciding policy responses and to those who are responsible for implementing COVID-19 management and risk-mitigation strategies. The outbreak has forced the government to shift its focus from elimination of transmission to focusing on containment of serious COVID-19 illness as it accelerates a delayed vaccination program. As Bennett observes "we are now drawn into the more compelling global experiment to find a workable, ethical and economically sustainable approach to controlling disease incidence and hospitalisations". 
Public health and medical science have enjoyed overriding attention in policy making in most countries over the past 18 months. In Australia, as in other countries, widespread vaccination combined with effective suppression is now delivering a range of more contestable policy options - to balance public health outcomes with the social, economic and mental health consequences of previously necessary public health measures. Our third COVID-19 paper from Brenna and colleagues in Canada illustrates the widespread concern about the mental health consequences of lockdowns and social dislocation caused by essential public health measures. ${ }^{3}$ It describes research examining necessary adaptations to service provision, especially for vulnerable people including older and dependent adults. The authors advocate for the uptake and validation of virtual suicide risk assessment tools, including telemedicine, smartphone apps and internet-based tools, in combination with existing assessment tools and approaches.

The Tyson-Holyfield fight was one of the more notorious in boxing history, ending when Tyson was disqualified for biting off part of Holyfield's ear. Holyfield did have a plan to beat Tyson, but Tyson's ferocity and unpredictability required Holyfield to continuously adapt in real time. Although the odds were greatly in favour of a Tyson win, Holyfield's ability to quickly and continuously adapt to circumstances saw him ahead on points compared with an increasingly frustrated Tyson before the fight was halted. The three papers examining our response to COVID-19 in this edition of the Journal show how our public health response also has to be one of continuous adaptation to a ferocious and unpredictable foe.

\section{Peer review and provenance}

Internally reviewed, invited.

\section{Competing interests}

None declared.

\section{Author contributions}

DN is the sole author.

\section{References}

1. Capon A, Sheppeard V, Gonzalez N, Draper J, Zhu A, Browne M, Sullivan E, Mihajlovic M, Rockett R, Ferson MJ. Bondi and beyond. Lessons from three waves of COVID-19 from 2020. Public Health Res Pract. 2021;31(2):e3132112.

2. Bennett CM. Learning to live with COVID-19: time for a new approach. Public Health Res Pract. 2021;31(3):e3132110

3. Brenna CTA, Links PS, Tran MM, Sinyor M, Heisel MJ, Hatcher S. Innovations in suicide as-sessment and prevention during pandemics. Public Health Res Pract. 2021;31(3):e3132111

\section{Copyright: (c) (i) (2) (2)}

(c) 2021 Nutbeam. This article is licensed under the Creative Commons Attribution-NonCommercial-ShareAlike 4.0 International Licence, which allows others to redistribute, adapt and share this work non-commercially provided they attribute the work and any adapted version of it is distributed under the same Creative Commons licence terms. See: www.creativecommons.org/licenses/by-nc-sa/4.0/ 